\title{
СУЧАСНІ КОМУНІКАЦЇ̈: РОЛЬ ТА ВПЛИВ НА ФОРМУВАННЯ КОМПЕТЕНТНОСТЕЙ СТУДЕНТІВ У ПРОЦЕСІ ВИВЧЕННЯ МОВИ
}

Скибун Н. Д.

\section{ВСТУП}

Стрімкий розвиток науково-технічного прогресу та темпи впровадження його результатів у широке комерційне використання створюють передумови до змін та трансформацій моделей цивілізаційного розвитку суспільства. Так, у 50-60-х роках XX століття, коли почалися комерційне використання технології передачі зображення на великі відстані (телебачення), обчислювальної техніки (комп'ютери), програмне забезпечення та цифровізація інформації, стартував процес зародження нового інформаційного суспільства. Вказане відбувається на фоні подальшої цифровізації інформації, комунікацій, інформаційних (оброблення, передавання, отримання, збереження та захист інформації) та комунікативних процесів. Але це був тільки початок. За останні 50-70 років інформаційно-комунікаційні технології, технічне та кінцеве обладнання кардинально змінилося порівняно із тим, з якого все починалося. Так, нині малопотужний комп'ютер, нетбук, смартфон за технічними показниками навіть не можна порівнювати з першими комп'ютерами, беручи до уваги такі показники інформаційних процесів, як швидкість $і$ обсяги передачі даних та обсяги збереження. При цьому завдяки електронним комунікаціям такий показник, як час, втратив актуальність, з огляду застосування цифрових форматів інформації та можливостей практично моментальної іїі передачі. Водночас необхідно зазначити, що головною ознакою ефективності та технологічності (використання новітніх технологій) $є$ постійне зменшення вартості технології і засобів збереження інформації. Пріоритетними завданнями, що стоять перед владою, нині $\epsilon$ створення умов покриття високошвидкісним інтернетом усієї території країни, інтеграція національного інтернет-простору у світовий, а також засобами комунікації якомога більшої кількості населення. Це сприятиме широкому впровадженню проектів інформатизації в рамках «цифрового суспільства», «цифрового уряду» та «цифрової економіки». Так, у рамках «цифрового суспільства» отримують підтримку з боку 
національної влади та міжнародних інституцій заходи зі створення нового цифрового середовища для людини та задоволення постійно зростаючих потреб. Перш за все це стосується соціальної сфери, де освіта відіграє основну роль 3 огляду на реалії сьогодення, а тому увага до дистанційної освіти та е-освіти тільки зростає, оскільки темпи змін традиційного середовища (людського буття, життєвого світу, місця роботи, професії) відбуваються постійно, а тому пристосування до нових реалій потребує нових знань. Також варто зазначити, що діджиталізація людського буття відбувається разом із процесами глобалізації та уніфікації усіх сфер суспільства та суспільних процесів, у тому числі у сфері освіти та отримання професійних навичок, що можна побачити на збільшенні кількісних та якісних показників різних навчальних продуктів, створених на глобальних науково-освітніх платформах i направлених для глобального використання. Вказане потребує уніфікації комунікацій (форм, методів, механізмів та інструментів) та можливості доступу до них, що потребує певного рівня цифрових навичок і знань (IT-компетентності), а для набуття професійної компетентності - достатньо-необхідного рівня мовної та мовленнєвої компетентностей. Разом це все потребує комунікативної компетентності.

Необхідно зазначити, що інформаційно-комунікаційні технології, комп'ютеризацію та інформатизацію необхідно розглядати лише як каталізатор змін та трансформацій, які відбуваються нині, а саме: нові комунікації (взаємовідносини) між людиною-суспільством-владою в контексті сучасної свободи, рівності, гідності, толерантності, мультикультуралізму, універсалізму, глобалізації, а також формування нової аргументативної етики та комунікативної влади на фоні появи нового суспільства, поділу на нові класи, нові погляди на людське буття. В таких умовах змінюється сама сутність освіти (потреба, набуття), зміна освітніх процесів та освітніх комунікацій, коли відбувається переосмислення самих процесів навчання в умовах нової школи, нової вищої освіти, які базуються на сучасних потребах та запитах.

3 огляду на вищевказане, а також сучасні виклики, які мають місце сьогодні (карантинні заходи у зв'язку із поширенням коронавірусу COVID-19), дослідження ролі та впливу сучасних комунікацій та засобів масових комунікацій на формування компетентностей у студентів у процесі вивчення мови набуває актуальності та затребуваності. Адже вказані події корінним чином впливають на саму сферу освіти в країні та освітні комунікації, що трансформуються в нові, сформовані на нових підходах та вимогах до підвищення рівня мобільності під час освітнього процесу на рівні вищих навчальних закладів країни. Адже наша країна досить тривалий час тільки 
декларувала впровадження нових технологій та комунікацій у соціальну сферу, незважаючи на поширення інтеграційних процесів в освітній сфері, в першу чергу на регіональному рівні (в рамках Угоди між ЄC та Україною), коли громадяни нашої країни отримали змогу навчатися та стажуватися у Вищих навчальних закладах $\mathrm{EC}$, а національні Вищі навчальні заклади (далі - ВНЗ) - співпрацю та координацію навчальних процесів, навчальних програм, а також стажування та обмін досвіду на рівні викладачів та студентів. Також наша країна $\epsilon$ учасником Болонського процесу, що також сприяє впровадженню нового, універсального та адаптованого освітнього процесу до загальноєвропейських підходів та вимог до освіти. Зрештою, це дає змогу національним ВНЗ трансформуватися в європейський освітній простір та готувати майбутніх фахівців високого рівня, які є конкурентоспроможними не тільки на європейському ринку праці, а й на світовому. Отже, можна говорити про те, що карантин i пов'язані $з$ ним заходи 3 ізоляції стали каталізатором, що прискорив широке впровадження на рівні національної освіти нових сучасних комунікацій під час освітнього процесу разом із широким використанням засобів масової комунікації під час навчання. Це може стати поштовхом до завершення проєкту «Нова українська школа» та створенню та впровадженню проєкту «Новий український ВНЗ», а напрацювання i досвід, отримані під проведення навчання під час карантину, стануть у нагоді. Адже наша країна досить повільно та «важко» інтегрується в новий сучасний глобальний навчальний простір, заснований, насамперед, на новому мисленні та категоріях, на яких формується нова освіта.

\section{1. Нова освіта в умовах нового постінформаційного та постекономічного світу}

Світ, в якому ми живемо, постійно трансформується та змінюється, але в сучасних реаліях науково-технічного прогресу та соціальноекономічних змін, що відбуваються на фоні цифрової та промислової революцій, коли суспільство починає комерційне використання штучного інтелекту, поєднання людини і машини, а також вплив на генетичному рівні не тільки на рослинний та тваринний світ, а й на саму людину. Отже, це вимагає високого рівня професійної компетентності, освіти та освіченості від фахівців та спеціалістів, що працюють над глобальними проектами. Окрім цього, необхідно зважати на мультикультуралізм, мультинаціональність та мультирелігійність команд, що виконують сучасні проєкти. А тому, окрім професійної компетентності, необхідна комунікативна та IT-компетентності. Але без мови як головного засобу комунікації неможливо 
працювати в мультикомандах, адже мовна та мовленнєві компетентності стають затребуваними в сучасному світі. Вказане повною мірою стосується не тільки професійної сфери, а й освітньої, адже без сучасної освіти неможливо стати сучасним професіоналом.

Так, дослідники суспільства, технологій, влади та відносин між ними, такі як 3. Бауман, О. Бард, Д. Белл, І. Берлін, Ю. Габермас, Е. Гуссерль, А. Єрмоленко, Я. Зодерквіст, В. Іноземцев, В. Мельник, А. Сен, Л. Ситніченко, Е. Тоффлер, Р. Флорід, А. Шюц, зазначають, що подальші трансформації розвитку інформаційного суспільства сприяли дискусіям навколо появи креативного класу та нетократії. Вказане стає підгрунтям формування нової парадигми свободи, в рамках якої відбувається перехід від «свободи від» («негативної свободи»), коли головними $є$ потреби держави до «свободи для» («позитивної свободи»), де на перше місце виходить задоволення потреб особистості (людини). Такий стан речей вимагає повноцінного діалогу (комунікації) між людиною і владою під час обговорення проблем, прийняття рішень 3 їх вирішення. Ось чому нового забарвлення отримують такі поняття, як свобода, рівність, гідність та толерантність. У таких умовах відбувається запит на нову владу, так звану комунікативну владу (деліберативна демократія), яка разом із новою демократією (так званою демократією 2.0) та новими взаємовідносинами між суспільством і владою (паноптикум 2.0) формують новий суспільний лад. Наступними важливими факторами впливу виступають глобалізація та віртуалізація взаємовідносин на рівні «людина суспільство - влада», які створили підвалини нового «кочового суспільства» та віртуального простору, коли людина стає вільною в переміщенні у просторових конструкціях людського буття (як фізичному, так і віртуальному). Особливо варто зазначити, що такі корінні зміни відбуваються в суспільстві досить стрімко (якихось 20-30 років) і кардинально, змінюючи парадигму людського буття так, що його вже не можна порівнювати зі станом людини не тільки в традиційному часі, a i на початку формування інформаційного суспільства. Такі переломні моменти вимагають пристосування до нових реалій постінформаційного та постекономічного суспільства. Ось чому на перший план виходить освіта усіх рівнів, яка має задовольняти суспільство щодо отримання нових знань, умінь та навичок. Адже, як ми усі добре знаємо, знання, освіченість, уміння та навички не беруться просто так, а вимагають кропіткої праці над собою (саморозвитку, самомотивації, самоорганізації, самоосвіти) вкупі 3 отриманням високоякісної освіти та «космополітичного» світоглядного бачення завтрашнього дня. Тобто можна $з$ упевненістю говорити, що значного розвитку та успіху у створенні процвітаючої сучасної країни 
можна досягти тільки завдяки створенню умов для розвитку кожного окремого громадянина для забезпечення високого рівня наукового та професійного потенціалів країни. Прикладами можуть слугувати ті країни, які досягли значних успіхів у розвитку, який базується не на корисних копалинах, а на людському ресурсі. Це, насамперед, Китай, Індія, Сінгапур, Південна Корея, Ірландія тощо. Вказані країни виростили свій новий клас професіоналів завдяки вкладанню значної частки національного ресурсу в освіту взагалі та особливу підтримку обдарованої молоді шляхом направлення на навчання до провідних світових ВН3 i, що особливо показово, - шляхом створення власної високорозвиненої освітньої сфери. Перш за все це стало можливим за умови досягнення високого рівня комунікативної, мовної та мовленнєвої компетентностей як серед студентів, так і викладачів, адже в умовах глобалізації (на світовому та регіональному рівнях) значна частина інформації та інформаційного простору (навчального, наукового та професійного) створюється глобальною мовою. Тому студенти і викладачі з країн, мова яких не входить до глобальних мов, змушені за допомогою комунікативної компетентності піднімати рівень мовної та мовленнєвої компетентностей іноземних мов. Так, О. Бард та Я. Зодервіст у праці «Netoкратія. Нова правляча еліта і життя після капіталізму» зазначають таке: «Інформація створює цивілізації», а «розвиток технологій не тільки змінює передумови для тих чи інших дій, але, змінюючи способи обміну і перерозподілу інформації, призводить до переоцінки всіх раніше існуючих уявлень про світ», тому «закономірним наслідком технологічної революції стає поява нової історичної парадигми», а «з розвитком комунікацій суспільне життя приймає все більш складні форми» при цьому «мова забезпечує здатність інноваційного мислення укупі з нескінченними виразними i творчими можливостями» ${ }^{1}$. Своєю чергою, Л. Ситніченко зазначає, що «поширення ставлення до мовної комунікації, мови та мовлення як до граничного начала людського розуміння світу та само розуміння» створює «умови для усвідомлення ролі й місця комунікації в сучасному суспільстві», де «комунікація є останнім підгрунтям (letzbegrQndung) i свідомості, і пізнання, і суспільного буття» ${ }^{2}$. Отже, можна говорити про те, що високий рівень мовної та мовленнєвої компетентностей досить вдало бере участь у формуванні IT-компетентності, комунікативної та професійної компетентностей такого високого рівня, щоб майбутній

1 Барда О., Зодервіст Я. Nеtократия. Новая правящая элита и жизнь после капитализма : Стокгольмская школа экономики. Санкт-Петербург, 2005. С. 13.

2 Ситніченко Л. Першоджерела комунікативної філософії. Київ : Либідь, 1996. C. 7. 
фахівець був конкурентоспроможним на глобальному ринку праці та у сфері наукових досліджень. Адже, як зазначає Р. Флоріда у праці «Креативний клас: люди, які змінюють майбутнє», поступово клас професіоналів трансформується в новий креативний клас. Як наголошує далі Р. Флоріда, поступово капітал та бізнес переміщуються в центри концентрації креативного класу для можливості ведення успішного бізнесу в умовах зміни парадигми погляду на будь-яку річ. Такий стан речей з'явився після буму виробництва та споживання речей, вироблених на потужностях великих підприємств у великій кількості для задоволення потреб першої необхідності. Так, пізній капіталізм (індустріальний період розвитку суспільства) позначався великими виробництвами із залученням значної кількості людей для масового вироблення товарів першої необхідності. Це вимагало створення відповідної інфраструктури для навчання, виховання, i, найголовніше, нагляду за великою кількістю людей. Ось у той період i виник запит на людину, яка може працювати на масовому виробництві, виконуючи простий відповідний обсяг роботи. Якраз у цей час людина і стала тим самим «Гвинтиком» великого механізму. У таких умовах навчання та виховання було зосереджене на формуванні такого типу людини в суспільстві. На сучасному етапі розвитку суспільства, коли на великих виробництвах переважна частина робіт автоматизована та виконується роботами, держава зосереджує увагу на людині 3 iii потребами (фізичними і духовними) i, найголовніше, влада починає чесний аргументативний діалог із громадянами на предмет спільного вирішення проблем, що постають перед суспільством і державою. Тобто у високорозвинених країнах настає момент, коли на державному рівні забезпечується для широких верств населення мінімальний рівень життя, який вищий, ніж рівень забезпечення фізичного виживання, створений демократичний діалог, забезпечується високий рівень фізичної та суспільної свободи та можливість для самореалізації, відбувається зміна парадигми людського буття. О. Бард та Я. Зодерквіст наголошують на тому, що «коли раціоналізм складає зброю, а на його місці залишається вакуум», який «може бути заповнений лише за допомогою живопису, літератури, музики і всіх інших гібридних форм мистецтва, що відкрилися завдяки новим технологіям», адже «творчі можливості практично невичерпні», а «зворотний бік медалі мистецтва, навіть більше ніж раніше, стане ексклюзивною провінцією мережевих племен» ${ }^{3}$. Тобто з'явився запит на креативне мислення, що знову повністю змінило підходи до

3 Барда О., Зодервіст Я. Nеtократия. Новая правящая элита и жизнь после капитализма : Стокгольмская школа экономики. Санкт-Петербург, 2005. 
виховання та навчання громадян. Адже на базі традиційної школи та ВН3 неможливо сформувати креативну особистість. Таким чином, формування креативності знову таки можливе за умови високого рівня компетентності, насамперед комунікативної, мовної та мовленнєвої. Варто зазначити, що креативними центрами є сучасні мегаполіси, а тому переїзд до них вимагає, окрім вказаних компетентностей, ще й мобільну компетентність - здатність до переїздів на нові місця навчання, роботи. Так, мобільність суспільства є основною ознакою як інформаційного суспільства, так і постінформаційного суспільства. 3. Бауман зазначає: «Найпотужнішим i жаданим фактором розшарування у світі стала мобільність: це та субстанція, з якої щодня будуються і перебудовуються нові, все більш глобальні соціальні, політичні, економічні та культурні ієрархії» ${ }^{4}$. Адже, як зазначають О. Бард та Я. Зодерквіст, «розвиток інформаційного суспільства призведе до значної міграції людей», коли «міграція нижчих класів відбуватиметься 3 областей iз низьким рівнем життя i високою народжуваністю в області 3 більш високим рівнем життя і низькою народжуваністю», оскільки «краще підстригати галявини, готувати тандурних курчат і отримувати за це зарплату, будучи громадянами областей із високим попитом і високою купівельною спроможністю» ${ }^{5}$, ніж тягнути жебрацьке існування на традиційному місці існування. Це, своєю чергою, призводить до того, що усі професіонали та креативники переміщаються в інші міста (території), бо «нижчі класи безперервно відчувають витік талантів i, відповідно, потенційних лідерів», а «еліта постійно посилюється за рахунок постійного оновлення і вливання нових талантів» ${ }^{6}$. Так, сучасна масова міграція та переміщення на нові місця роботи руйнують традиційні цінності осілого життя: сім'я, власне майно, стале коло звичок, друзів та засобів відпочину тощо. Так, 3. Бауман твердить, що «найпотужнішим i жаданим фактором розшарування в світі стала мобільність: це та субстанція, з якої щодня будуються і перебудовуються нові, все більш глобальні соціальні, політичні, економічні та культурні ієрархії» ${ }^{7}$. При цьому «працевлаштування перестало бути довічним, і стаж роботи не має вже першорядного значення», оскільки «бізнес-організації стають менш жорсткими і дедалі більше концентруються на короткострокових

\footnotetext{
${ }^{4}$ Бауман 3. Глобализация. Последствия для человека и общества / Пер. с англ. Москва : Издательство «Весь Мир», 2004. С. 19.

5 Барда О., Зодервіст Я. Netoкратия. Новая правящая элита и жизнь после капитализма : Стокгольмская школа экономики. Санкт-Петербург, 2005. С. 94.

${ }^{6}$ Там само.

${ }^{7}$ Бауман 3. Глобализация. Последствия для человека и общества / Пер. с англ. Москва : Издательство «Весь Мир», 2004. С. 21.
} 
проектах, для яких кожен раз потрібні люди 3 певними навичками», тому «такі тимчасові утворення створюються лише для того, щоб розпастися після завершення проекту» i, найголовніше, «освіта не може бути закінченою главою, вона повинна постійно оновлюватися», бо «кожна нова задача виникає в принципово відмінних від колишніх умовах, що кожен раз вимагає нових знань» ${ }^{8}$. Тобто сучасна людина змушена часто змінювати професійну компетентність залежно від нових завдань, а це вимагає постійного навчання впродовж усього життя. Р. Флоріда говорить про це так: «У новому світі нас визначають вже не організації, на які ми працюємо, не церкви, не місцеві спільноти і навіть не сімейні узи», а «ми робимо це самі, моделюючи свою ідентичність відповідно до різних сторін власної креативності», де «інші аспекти нашого життя - об'єкти споживання, нові форми дозвілля та відпочинку, заходи 3 організації спільнот - вибудовуються вже навколо цього процесу творення ідентичності» ${ }^{9}$. Таким чином, повертаючись до теми нашого дослідження, можна говорити про те, що в сучасному світі «місце під сонцем» зможуть вибороти ті особистості, які завдяки самоорганізації, самоконтролю та здатності до навчання підвищувати рівень компетентностей до бажано достатнього рівня. I найголовніше, що нині перед людиною відкриваються практично необмежені можливості щодо навчання. Перш за все, завдяки сучасним можливостям щодо міжконтинентальних переміщень людина може вибрати будь-яке місце навчання, а завдяки уніфікації та стандартизації освітнього процесу адаптація до нового місця навчання буде мінімальною. При цьому необхідно зазначити, що сучасний розвиток засобів комунікації, інформаційних та комунікативних процесів трансформує традиційні форми і методи навчання, адаптуючи їх до нових реалій. Таким чином, відбувається поширення можливостей отримання знань, оскільки до нових комунікативних процесів долучаються практично усі, в кого є доступ до телекомунікацій та відповідне сучасне кінцеве обладнання, а тому «використання електронних інформаційних засобів (телефону, радіо, телебачення i комп'ютерів), глобальне і локальне, наблизилися один до одного», перетинаючи національні кордони і континенти, тим самим стаючи наднаціональним (глобальним) ${ }^{10}$. Адже, як зазначає Л. Мельник у монографії «Соціально-економічні проблеми інформаційного суспільства», «безпрецедентні явища віртуалізації і глобалізації

8 Барда О., Зодервіст Я. Nеtократия. Новая правящая элита и жизнь после капитализма : Стокгольмская школа экономики. Санкт-Петербург, 2005. С. 159.

${ }^{9}$ Флорида Р. Креативный класс: люди, которые меняют будущее / Пер. с англ. Москва : Издательский дом «Классика-XX1», 2007. 421 с.

${ }^{10}$ Гидденс Э. Социология / Едиториал УРСС, 1999. С. 322. 
людського буття, колосальне нарощування та інтеграція систем соціальної пам'яті істотно видозмінюють просторово-часові масштаби життя i діяльності людини», даючи «можливість отримувати інформацію 3 минулого i майбутнього, а крім того, формувати i прораховувати на віртуальному рівні різні сценарії розвитку систем, у тому числі і всієї людської цивілізації», що «значно збільшує потенціал виробничих систем, відчутно підвищує ефективність людської діяльності, різко підвищує темпи соціально-економічного розвитку» ${ }^{11}$. Адже можна говорити про те, що «засоби масової інформації не тільки пропонують розваги, але надають і структурують більшу частину тієї інформації, якою ми користуємося в повсякденному житті» ${ }^{12}$, що підходить і до освітнього процесу загалом і окремих освітніх проектів, в яких використовуються як засоби масової інформації, так і масової комунікації, де головною відмінністю $є$ можливість налагодження діалогу в режимі реального часу, незважаючи на відстань, час, країну, національність та віросповідання. Головним критерієм такого діалогу $€$ налагодження зрозумілої обом сторонам комунікації, в якій мова постає важливим комунікатором, а тому достатньо високий рівень мовної та мовленнєвої компетентностей стає визначальним.

\section{2. Нові комунікації та засоби комунікацій в освіті та новітні інструменти навчання}

Разом із новими технологіями та технічними прогресом відбувалися зміни в освітній сфері та освітній комунікації. Так, «із винаходом писемності все стало легко досяжним і пізнаваним», коли «зростання обсягу доступної інформації отримало вибуховий характер, і все завдяки геніальному винаходу візуального коду для комунікацій», а «інтелектуальне життя стало вельми насиченим», адже, «маючи на руках добре сконструйований, при цьому фонетичний, а не складовий алфавіт, <..> стародавні греки створили філософію та інші базові науки», при цьому «заміна вуха на око як основного засобу лінгвістичного сприйняття справила радикальний переворот у нашому розумінні світу» ${ }^{13}$. Далі 3 винаходом друкованого верстату та розвитком поштового зв'язку стало можливим поширення друкованих видань та письмових завдань на великі відстані. Такі комунікаційні

11 Социально-экономические проблемы информационного общества : монография / Под ред. Л.Г. Мельника, М.В. Брюханова. Выпуск 2. Сумы : Университетская книга, 2010. С. 12.

${ }^{12}$ Гидденс Э. Устроение общества: Очерк теории структурами. 2-е изд. Москва : Академический Проект, 2005. С. 322.

13 Барда О., Зодервіст Я. Netократия. Новая правящая элита и жизнь после капитализма : Стокгольмская школа экономики. Санкт-Петербург, 2005. С. 8. 
технології, як радіо та телебачення, дали змогу проводити дистанційне навчання в реальному часі (аудіо- та відеоуроки), які отримали значну популярність у країнах із великими територіями та низькою щільністю населення. Але з часом та розвитком нових технологій комунікації ці методи навчання (аудіо- та відеоуроки за допомогою таких засобів масової інформації, як радіо та телебачення) поступово трансформувалися в новий інструментарій. Але при цьому треба зазначити, що ніхто не відміняв звичайного усного спілкування, листування та видання друкованої літератури. Яскравим прикладом поєднання усіх наявних засобів і методів комунікації $є$ традиційний навчальний процес у ВНЗ, де $є$ лекції, практичні заняття, тести, лабораторні заняття, самостійна робота 3 підручниками та додатковою літературою тощо. Що стосується цифровізації, віртуалізації, мультимедіа, використання освітніх платформ у навчальному процесі, то ситуація тут $\epsilon$ досить строкатою та нерівномірною за рівнем використання в національних ВНЗ.

3 огляду на рівень поширення новітніх технологій у сфері освіти питання сучасного дискурсу досить широко представлено на рівні наукових досліджень, серед яких можна зазначити таких дослідників, як О. Бігуненко, А. Блозва, Р. Гуревич, Л. Куниця, І. Кокуть, О. Кальна, І. Колесніченко, О. Миронова, Г. Сиротенко, С. Руда, Н. Тверезовська, Л. Шапран, Л. Шульга, Г. Чередніченко тощо.

Так, певні приклади широкого використання новітніх технологій мають точковий та епізодичний характер і залежать в основному від особистої зацікавленості керівництва ВНЗ, окремих кафедр та факультетів. Але треба зазначити, що події цього року, спричинені пандемією коронавірусу та заходами із закриттям традиційної форми навчання у навчальних закладах усіх рівнів виступили дієвим каталізатором для швидкої перебудови національної освіти на нові сучасні форми і методи навчання, які поєднали в собі традиційні форми дистанційного навчання разом із використанням сучасних комунікацій, а також самоосвіту.

Так, можна зазначити, що використання таких засобів масової інформації, як радіо та телебачення, дає змогк охопити значну аудиторію, але така масовість, на наш погляд, підходить лише для надання загальноосвітнього теоретичного матеріалу 3 базових предметів, що ми і бачимо нині на прикладі викладання шкільних предметів під час карантину. Що стосується вузькопрофільних предметів у вищій школі, то вказана комунікаційна платформа не забезпечить більш тісної комунікації (аргументативного діалогу) на рівні викладач-студент. При цьому створення окремих телевізійних та радіоканалів для всіх вузькопрофільних ВНЗ потребуватиме значного 
часу та ресурсів як для забезпечення надійного каналу комунікації, так i для підготовки відповідних навчальних програм, методичного та методологічного забезпечення викладачів та студентів. Але самі по собі аудіо- та відеоуроки $є$ досить поширеною формою навчання, особливо у сфері вивчення іноземних мов як під час дистанційного навчання, так i додатково під час традиційного навчання. Зважаючи на подальший розвиток технологій та техніки комунікації, суспільство отримало для широкого використання нових комунікацій сучасну платформу глобальну мережу передачі даних (Інтернет), яка завдяки міжнародним електронним комунікаціям увійшла практично в кожен дім за допомогою мобільного (рухомого) зв'язку та широкополосного інтернету. Завдяки новим можливостям технологій та комунікаційних мереж засоби масової інформації отримали можливість інтерактивного діалогу, що стало поштовхом до появи так званих засобів масової комунікації (ЗМК). «Інтернет - це щось зовсім нове. Засіб, завдяки якому практично будь-яка людина після порівняно невеликих інвестицій в обладнання та за допомогою кількох простих дій може стати одночасно і творцем, i споживачем тексту, образів і звуків. Важко собі уявити щось більш могутнє. У Мережі ми всі і автори, і видавці, і продюсери. Наша свобода самовираження колосальна, а аудиторія неозора велика. Простим натисненням кнопки будь-яка інформація стає негайно доступною. Масштаби розвитку цього засобу комунікації не мають собі рівних» ${ }^{14}$. Отже, інтернет як нова комунікаційна платформа позитивним чином вплинула на формування нового типу комунікацій під час навчального процесу, а також створення віртуальних освітніх проектів, у рамках яких у повному обсязі розкрилися можливості мультимедіа як засобів навчання. I, найголовніше, вказані процеси відбуваються поза фізичними кордонами окремих країн, що збільшує можливості навчання у ВНЗ дистанційно. Своєю чергою С. Руда, розглядаючи «інтернет як базу виникнення комунікативного середовища без кордонів», наголошує на тому, що «інтернет-дискурс» $\epsilon$ багатожанровим функціональним різновидом монологічного та діалогічного спілкування, характеризується цілою низкою специфічних комунікативних засобів», тому «своєрідність електронного спілкування полягає не тільки у використанні «професіоналізмів», а й у комбінації лексичних одиниць, що належать до різних стилів і регістрів та обираються відповідно до прагматичних установок й мети спілкування в електронній мережі» ${ }^{15}$.

14 Барда О., Зодервіст Я. Nеtократия. Новая правящая элита и жизнь после капитализма : Стокгольмская школа экономики. Санкт-Петербург, 2005. С. 9.

15 Руда С.В. Інтернет як база виникнення комунікативного середовища без кордонів. Науковий вісник Національного університету біоресурсів $i$ природокористування Украӥни. Серія «Педагогіка. Психологія. Філософія». 2011. Випуск 159. Ч. 2. С. 159. 
Отже, формування глобальної мережі передачі даних разом із новими комунікаціями стало передумовою появи нового комунікативного дискурсу, в умовах, коли «характерною ознакою «інтернет-дискурсу» $\epsilon$ інтерактивність», яка насамперед «проявляється у зміцненні адресатних зв'язків, тобто у посиленні взаємовпливу учасників мовної комунікації, що відбувається через новітні канали спілкування» ${ }^{16}$. Але вказані заходи залежать, насамперед, від рівня проникнення новітніх комунікаційних технологій у навчальний процес ВН3, цифрової (інформаційної) та IT-компетентності викладачів і готовності самих студентів до отримання сучасної освіти по-новому. На вказаному наголошують А. Блозва та Н. Тверезовська в рамках дослідження «інформаційної грамотності як фактора підвищення якості сучасної освіти», які пропонують до нашої уваги перелік таких компетентностей: «уміння знаходити необхідну інформацію для професійної та повсякденної діяльності, користуватися цією інформацією, аналізувати, синтезувати, оцінювати як саму інформацію, так і іiі джерела, використовуючи при цьому новітні інформаційні та телекомунікаційні технології» ${ }^{17}$. Тобто для того, щоб повною мірою використовувати нові комунікації в навчальному процесі, необхідно сформувати достатній рівень не тільки традиційної комунікативної компетентності, а й нової інформаційнокомунікативної (IT-компетентності та цифрової грамотності) компетентності усіх учасників навчального процесу для можливості ведення сучасного комунікативного дискурсу у віртуальному просторі під час навчання. Наприклад, А. Блозва та Н. Тверезовська пропонують «такі форми навчання» для підвищення рівня «інформаційної грамотності»: «семінари-тренінги, присвячені онлайновим каталогам, базам даних та іншим подібним ресурсам; спеціальні навчальні курси 3 інформаційної грамотності, що входять до навчальних планів ВНЗ; тренінги щодо використання інформаційних ресурсів, які орієнтовані на підтримку конкретних академічних груп; інтерактивні навчальні програми, що реалізуються через вебсайти; електронні демонстрації з практичними завданнями; вправи 3 використанням електронних ресурсів, які самостійно

16 Руда С.В. Інтернет як база виникнення комунікативного середовища без кордонів. Науковий вісник Національного університету біоресурсів $i$ природокористування України. Серія «Педагогіка. Психологія. Філософія». 2011. Випуск 159. Ч. 2. С. 159. С. 160.

17 Блозва А.І., Тверезовська Н.Т. Інформаційна грамотність як фактор підвищення якості сучасної освіти. Науковий вісник Національного університету біоресурсів $i$ природокористування Украӥни. Серія «Педагогіка. Психологія. Філософія». 2011. Випуск 159. Ч. 2. С. 165. 
виконуються малими трупами користувачів» ${ }^{18}$. Отже, підвищення базового рівня інформаційно-комунікаційної компетентності для можливості використання широкого спектру можливостей, які відкриваються завдяки використанню в навчальному процесі можливостей інтернету, ЗМК та новітніх технологій, сприяє «виникненню та розвитку специфічного навчального середовища - так званого середовища віртуальної реальності», що «привело до зміни складу i структури методичних систем» ${ }^{19}$, а також широкому впровадженню «електронних навчальних посібників, електронних навчально-методичних комплексів із різних дисциплін, курсів, які розміщені на сайтах навчальних закладів у мережі Інтернет, локальних мережах, а також на електронних носіях» ${ }^{20}$, створивши тим самим передумови появи інформаційного освітнього середовища, яке відкрило нові можливості «здійснення неперервного навчання: еlearning, m-learning, blended-learning», забезпечивши «інформаційну, інтерактивну, комунікаційну, координуючу, культуроформальну, розвивальну і професійно-орієнтовану» функції ${ }^{21}$. Адже, як наголошує Г. Бакулєв, «медіаінститути зайняті виробництвом, відтворенням і розподілом знань у найширшому сенсі, набором символів, що містять смислове посилання на досвід у громадському світі», які «дають змогу людям осмислити досвід, сформувати уявлення про нього, поповнити запас відомостей про минуле і усвідомити сучасність», адже «вони виконують функцію загального носія знань різного роду - також і від імені інших інститутів; вони діють у громадській сфері, в принципі доступні для всіх членів суспільства на відкритій, добровільній, неспецифічній і недорогій основі; <..> медіа охоплюють більше людей, ніж інші інститути, й протягом більшого часу, «беручи естафету» від початкового впливу школи, батьків, релігії тощо» ${ }^{22}$. А тому можна говорити про те, що створення інформаційного освітнього середовища сприятиме «підвищенню якості освіти, вдосконаленню системи традиційного та дистанційного навчання, окрім цього, зменшити витрати на навчання, можливість здійснення

18 Блозва А.І., Тверезовська Н.Т. Інформаційна грамотність як фактор підвищення якості сучасної освіти. Науковий вісник Національного університету біоресурсів $і$ природокористування України. Серія «Педагогіка. Психологія. Філософія». 2011. Випуск 159. Ч. 2. С. 167-168.

19 Гуревич Р.С. Інформаційно-комунікаційні технології в професійній освіті майбутніх фахівців / Р.С. Гуревич, М.Ю. Кадемія, М.М. Козяр. Львів : Вид-во «СПОЛОМ», 2012. С. 396.

${ }^{20}$ Там само. С. 339.

${ }^{21}$ Там само. С. $395,396$.

22 Бакулев Г.П. Массовая коммуникация: Западные теории и концепции. Москва : Аспект Пресс, 2005. С. 5-6. 
неперервного навчання» ${ }^{23}$. Враховуючи сучасні тренди, що стосуються високого рівня мобільності серед студентів, а також формування глобальних осередків навчання на базі визнаних світовою спільнотою традиційних ВН3 із високим рівнем викладання, багаторічними традиціями та сформованою педагогічною школою, представленою педагогами високого рівня з усього світу. Вказане створює передумови затребуваності знаходження спільної мови в рамках мультикультуралізму, мультинаціоналізму та мультирелігійності як педагогічного колективу, так і студентів. Ось чому виникає запит на вивчення мов міжнаціонального спілкування та комунікацій. Що стосується нашої країни, то вказані процеси вивчення таких мов отримали значний поштовх після відкриття кордонів та збільшення рівня можливостей отримання вищої освіти у провідних вишах Європейського Союзу. У зв'язку з цим зріс попит на вивчення мов, що у сучасних умовах задовольняється як традиційними формами навчання, так i сучасними, які можна отримати самостійно та або дистанційно за допомогою великої кількості аудіо- та відеонавчальних матеріалів, коли «розвиток нових освітніх технологій наблизив до створення дистанційного навчання та нової генерації навчальних закладів - віртуальних (електронних) університетів, які мають зробити освіту доступнішою та підняти ії на якісно новий рівень» ${ }^{24}$. Особливої актуальності сучасні технології дистанційного навчання набули за межами великих міст. Таким чином, ми стаємо свідками поєднання традиційних ВНЗ із віртуальними (електронними) ВН3, що забезпечило змогу дистанційно навчатися студентам iз багатьох країн у провідних ВНЗ на віртуальному рівні, фізично перебуваючи дома. Це пов'язується 3 прагненням освіти відповідати сучасним тенденціям щодо розвитку особистості в умовах свободи, рівності, толерантності та прагненню в майбутнє, коли «такі терміни, як «особистісне зростання», «самоактуалізація», «прагнення до здоров'я», «пошук ідентичності та автономії», «потреба в досконалості» (та інші, що позначають спрямованість людини «вгору») слід прийняти і широко вживати вже тому, що вони описують загальні, а можливо, навіть універсальні людські тенденції» ${ }^{25}$. Так, Н. Скотна говорить: «3 огляду на вимоги, які ставляться до сучасного освітнього процесу, де на перше місце виходить «Людина знаюча та уміюча (так звана Людина компетентна), ось «кого власне ми хочемо отримати на

${ }^{23}$ Гуревич Р.С. Інформаційно-комунікаційні технології в професійній освіті майбутніх фахівців / Р.С. Гуревич, М.Ю. Кадемія, М.М. Козяр. Львів : Вид-во «СПОЛОМ», 2012. С. 396, 337.

${ }^{24}$ Там само. С. 395, 396.

25 Маслоу А. Мотивация и личность. 3-е изд. / Пер. с англ. Санкт-Петербург : Питер, 2009. С. 7. 
«виході» із системи вищої освіти» ${ }^{26}$. А для ВНЗ такі нові можливості забезпечують приток бажаючих отримати освіту та викладачів викладати у провідних сучасних ВНЗ. На наш погляд, вказані тенденції щодо віртуалізації ВНЗ будуть тільки зростати, з огляду на події у світі, пов'язані із карантином. Це стосується ВН3, які займаються підготовкою фахівців для глобального ринку праці та світової науки. Стосовно національного рівня, то створення віртуальних (електронних) ВНЗ на базі традиційних покращить рівень доступу до освіти вже для підготовки фахівців національного та/або регіонального рівня. Адже, як зазначає С. Руда, «інтернет-дискурс»- специфічний вид дискурсу, якому властива надзвичайно велика різноманітність, як за кількістю учасників, так і мов, якими відбувається спілкування, і тематики; це дискурс, який відбувається у «світовій павутині» - Інтернеті, де у наш час присутні практично всі сучасні писемні мови (близько п'яти тисяч)» ${ }^{27}$. Позитивним є те, що з огляду на поширення глобалізаційних процесів в усіх сферах суспільного життя та людського буття відбувається стандартизація та уніфікація навчальних процесів, а тому, отримавши освіту у національному ВНЗ, студент може продовжити навчання вже в іншому ВНЗ, який може знаходитися навіть на другому контенті, адже «студенти Свропи повинні мати право отримувати освітньо-професійні рівні, які будуть ефективно використовуватися не лише в тих країнах, де вони іх отримали, а й у всій Європі» за умови сприяння університетами та урядами «забезпеченню студентів відповідними до загальних вимог кваліфікаціями» ${ }^{28}$. Так, у рамках Болонського процесу зосереджено ВНЗ з 48 країн, а тому «Болонський процес веде до більшої сумісності та порівнянності систем вищої освіти, завдяки чому для учнів полегшується мобільність, а для вищих навчальних закладів залучення студентів і вчених 3 інших континентів» ${ }^{29}$. Головним стримуючим фактором виступає комунікація іноземною мовою. А тому, зважаючи на набутий досвід щодо дистанційного навчання, необхідно говорити про необхідність створення на державному рівні спеціалізованого освітнього електронного ресурсу, де мають бути зібрані на одній платформі усі навчальні ресурси за фаховими

${ }^{26}$ Скотна Н. Сутність глобалізації та ії вплив на розвиток вищої освіти в Україні. Людинознавчі студії. Філософія. Випуск 28. С. 14.

27 Руда С.В. Інтернет як база виникнення комунікативного середовища без кордонів. Науковий вісник Національного університету біоресурсів $i$ природокористування Украӥни. Серія «Педагогіка. Психологія. Філософія». 2011. Випуск 159. Ч. 2. С. 158.

28 Пінчук С.А. Модернізація вищої школи України в умовах інтеграції в європейський освітній простір. Формування європейського освітнього простору. Теорія і практика управління сочіальними системами. 2009. № 2. С. 114.

29 Европейское пространство высшего образования. URL: http://euroosvita.net/ ?category $=17 \& \mathrm{id}=1048$. 
напрямами. У процес створення та наповнення вказаного ресурсу необхідно залучити досвід усіх національних ВНЗ у частині дистанційної освіти та вибрати ресурси, платформу, методики навчання та механізми комунікації. Вказане має здійснюватися, зважаючи на досвід та стандарти створення таких ресурсів у рамках Європейського Союзу.

\section{ВИСНОВКИ}

Підсумовуючи питання ролі та впливу на формування компетентностей студентів у процесі вивчення мови в умовах сучасного етапу цивілізаційного розвитку суспільства, зазначимо, що сучасні трансформації та зміни, що відбуваються в суспільстві, мають всеохоплюючий та загальний характер. Так, сучасні дослідники наголошують на тому, що за останні десятиліття відбулися такі кардинальні зміни, що можна говорити навіть не про інформаційне суспільство, а про постінформаційне та постекономічне суспільство. В таких умовах відбуваються зрушення на ціннісному рівні, коли традиційні цінності втрачають вагу i перестають домінувати в суспільстві. Крім того, нове розуміння свободи як особистісної, так i суспільної формується на основі так званої позитивної свободи, коли потреби людини замінюють потреби держави. Разом із цим людина перестає бути «маленьким гвинтиком» і стає особистістю, розвиток якої відбувається вже в нових реаліях: свободи, рівності, гідності, толерантності, демократії, вільного ринку. Це змінює саму особистість, піднімає рівень самооцінки, самоосвіти, самоорганізації тощо. Таким чином відбувається формування нових вимог та підходів до самої освіти. При цьому відбувається подальша цифровізація інформації, інформаційних та комунікативних процесів, які разом із використанням інформаційно-комунікативних технологій та інформатизації створюють нові можливості для нової освіти, заснованої на використанні інтернету, віртуального простору та сучасних освітніх платформ, засобів та інструментів. Крім того, на сферу освіти впливають глобалізація, уніфікація та мультикультуралізм в освіті. В таких умовах поряд із мовною та мовленнєвою компетентностями для отримання професійної компетентності виникає потреба у високому рівні комунікативної, інформаційної, цифрової та IT-компетентності як викладачів, так і студентів. Такі компетентності ми пропонуємо називати інформаційнокомунікаційні компетентності (IК-компетентності). Зважаючи, що технології та техніка йдуть уперед ІК-компетентності, необхідно розвивати на постійній основі. У зв'язку із зазначеним нами запропоновано створення національного спеціалізованого електронного освітнього ресурсу (Е-нацосвітресурс), в якому було б сконцентроване все необхідне для викладачів та студентів для можливого 
використання/застосування як для традиційного навчання, так і для дистанційного. При цьому створення, формування та наповнення Е-нацосвітресурсу має координуватися 3 аналогічними ресурсами, що створюються в Свропейському Союзі та провідних світових центріах вищої освіти на базі традиційних ВНЗ.

\section{АНОТАЦІЯ}

У рамках вказаного дослідження розглядалося питання ролі сучасного розвитку суспільства, нового суспільства та нової людини, нових комунікацій. Вказане $\epsilon$ показовим, адже нині науковці говорять вже не про інформаційне суспільство, а зародження постінформаційного та постекономічного суспільства, що накладає свій відбиток на саму людину, iї буття, іiі роль у сучасному суспільстві та державі. Також було зазначено посилення ролі засобів масової комунікації завдяки новій платформі масмедіа, сформованій на базі глобальної мережі передачі даних (Інтернет). Крім того, нові виклики створюють глобалізація, масові переміщення та зміна традиційних цінностей. Отже, це все впливає на всі сфери суспільства, в тому числі на освітню сферу, освітні процеси та освітню комунікацію, як на національному, так і на глобальному рівнях. Такі умови визначають необхідність стандартизації, уніфікації комунікацій на рівні освіти. Крім того, глобальний ринок праці та широкі можливості для навчання у вищих навчальних закладів (ВН3) усього світу створюють необхідність використання мов (глобального та регіонального рівнів) як засобів комунікації під час навчання у ВНЗ. У результаті проведеного дослідження було зазначено необхідність формування віртуальних ВНЗ на базі традиційних ВНЗ для розширення рівня можливостей доступу до освіти. Також було запропоновано створити національний спеціалізований електронний освітній ресурс (Е-нацосвітресурс), який би сконцентрував би в собі усе необхідне для викладачів та студентів в одному місці для можливого використання/застосування як для традиційного навчання, так i для дистанційного. При цьому було зазначено необхідність координації дій зі створення такого ресурсу із проєктами Європейського Союзу та провідних світових центрів вищої освіти на базі традиційних ВНЗ. Крім того, необхідно здійснювати на постійній основі підвищення рівня інформаційно-комунікаційної (цифрової, IT, інформаційної) компетентності студентів і викладачів.

\section{ЛІТЕРАТУРА}

1. Бакулев Г.П. Массовая коммуникация: Западные теории и концепции. Москва : Аспект Пресс, 2005. 176 с.

2. Барда О., Зодервіст Я. Netoкратия. Новая правящая элита и жизнь после капитализма : Стокгольмская школа экономики. СанктПетербург, 2005. 
3. Бауман 3. Глобализация. Последствия для человека и общества / Пер. с англ. Москва : Издательство «Весь Мир», 2004. 188 с.

4. Блозва А.І., Тверезовська Н.Т. Інформаційна грамотність як фактор підвищення якості сучасної освіти. Науковий вісник Наиіонального університету біоресурсів $i$ природокористування Украӥни. Серія «Педагогіка. Психологія. Філософія». 2011. Випуск 159. Ч. 2. С. $162-167$.

5. Гидденс Э. Социология / Едиториал УРСС, 1999. 704 с.

6. Гидденс Э. Устроение общества: Очерк теории структурами. 2-е изд. Москва : Академический Проект, 2005. 528 с.

7. Гуревич Р.С. Інформаційно-комунікаційні технології в професійній освіті майбутніх фахівців / Р.С. Гуревич, М.Ю. Кадемія, М.М. Козяр. Львів : Вид-во «СПОЛОМ», 2012. 502 с.

8. Европейское пространство высшего образования. URL: http://euroosvita.net/?category=17\&id=1048.

9. Маслоу А. Мотивация и личность. 3-е изд. / Пер. с англ. СанктПетербург : Питер, 2009. 352 с.

10. Пінчук Є.А. Модернізація вищої школи України в умовах інтеграції в європейський освітній простір. Формування європейського освітнього простору. Теорія $і$ практика управління соціальними системами. 2009. № 2. С. 112-120.

11. Руда С.В. Інтернет як база виникнення комунікативного середовища без кордонів. Науковий вісник Національного університету біоресурсів $i$ природокористування Украӥни. Серія «Педагогіка. Психологія. Філософія». 2011. Випуск 159. Ч. 2. 2011. С. 157-162.

12. Ситніченко Л. Першоджерела комунікативної філософії. Київ : Либідь, 1996. 176 с.

13. Скотна Н. Сутність глобалізації та її вплив на розвиток вищої освіти в Україні. Людинознавчі студіï. Філософія. Випуск 28. С. 5-16.

14. Социально-экономические проблемы информационного общества : монография / Под ред. Л.Г. Мельника, М.В. Брюханова. Выпуск 2. Сумы : Университетская книга, 2010. 896 с.

15. Флорида Р. Креативный класс: люди, которые меняют будущее / Пер. с англ. Москва : Издательский дом «Классика-XX1», 2007. 421 с.

\section{Information about the author: Skibun N. D.,}

Candidate of Pedagogical Sciences, Lecturer at the Chair of Ukrainian Studies Bogomolets National Medical University 34, Peremohy Avenue, Kyiv, 01601, Ukraine 